\title{
Capacity Identification and Operational Policy of the Proposed Broadlands Mini Hydroelectric Power Plant
}

\author{
R. K. N. P. Kumara, Lalith A. Samaliarachchi and Anuradha Mudannayake
}

\begin{abstract}
Broadlands Hydropower Project (BHP) with an installed capacity of $35 \mathrm{MW}$ and expected annual energy generation of 137 GWh will harness the last remaining hydropower potential of the Kehelgamu-Maskeli Oya (K-M) Complex located in Kitulgala area. The construction of the main dam of the BHP will directly affect White-Water Rafting (WWR) that takes place along the downstream of the said area. To sustain this sport activity which has become a tourist attraction, and to avoid conflicts that could arise among concerned parties, a certain quantity of water (yet to be decided) has to be released during day time from the main dam which would reduce the amount of annual energy that was originally expected to be generated from BHP. However, the possibility of recovering some of the lost energy by releasing the water through a mini hydroelectric power plant located downstream of Kelani River close to the BHP Main Dam cannot just be ignored. This research study therefore investigated the technical impact of releasing water under different operational policies through the main dam of the Broadlands Power Plant and the possibility of recovering the energy lost using the proposed mini hydroelectric power plant while catering to WWR. Finally, the economic impact of avoiding the cost of dispatching of thermal power plants under different operational scenarios of the composite power system as stated by the Ceylon Electricity Board (CEB) is presented.
\end{abstract}

Keywords: White-Water Rafting, Mini hydroelectric plant, Water value, Avoided cost of thermal plants.

\section{Introduction}

\subsection{Laxapana Complex}

The Laxapana Complex set up under the Kehelgamu-Maskeli Oya Development Project with five power stations operating in cascade, an installed capacity of $355 \mathrm{MW}$ and an annual energy generation of $1563 \mathrm{GWh}$ [5] is shown in Figure 1 in Appendix-A. Castlereagh and Maussakelle are the two main storage reservoirs feeding the complex.

\subsection{Broadlands Hydro Power Project}

Broadlands Hydro Power Project is the last large scale hydropower development project to be implemented for the Laxapana Complex. Its main work sites are located about $95 \mathrm{~km}$ away from Colombo. The 2x17.5 MW run-of-the-river type power plant currently under construction in Kithulgala area under the Project is expected to be completed in July 2019.

The Project consists of a weir, dam, water diversion tunnel, headrace tunnel and a power plant. The weir and dam are to be constructed in an area called Polpitiya in the Nuwara Eliya district in the Central Province, near the confluence of Maskeli-Oya and KehelgamuOya, the two main upstream tributaries of Kelani River. Broadlands main dam built across Maskeli-Oya will receive directly the water released from the existing Polpitiya Power Plant (PP). A weir that will be built across Kehelgamu-Oya will divert the catchment inflow from Norton Pond to Broadlands Pond through a short non-pressure tunnel. From there, the water will be taken to the power plant situated in the Kalukohutenna area in the Kegalle District of the Sabaragamuwa Province through the headrace tunnel which will be nearly $3.5 \mathrm{~km}$ in length. Water will be released back to Kelani River thereafter through a tailrace canal. The proposed arrangement of the Laxapana Complex is shown in Figure 2 in Appendix-A.

\subsection{White-Water Rafting (WWR)}

Kitulgala, a rain forest area, which is fortunate to receive both monsoons, is one of the wettest places in Sri Lanka and is in the process of being developed as a tourist base mainly to facilitate WWR related activities. WWR is an adventurous and exciting sport which attracts both foreigners and locals equally. Figure 3 in Appendix-A shows some photographs of recent WWR activities .

Mr. R.K.N.P. Kumara, B.Tech. Eng. (Hons)(OUSL),

Electrical Superintendent, Laxapana Power Plant, Ceylon Electricity Board.

Email:kumararknp@gmail.com.

Eng. Lalith A. Samaliarachchi, B.Sc. Eng. (Hons) (Moratuwa), M. Eng.(AIT), MIEE(UK), MIE(SL), C. Eng

Senior Lecturer, Department of Electrical \& Computer Engineering, The Open University of Sri Lanka.

Email:lasam@ou.ac.lk

Eng. Anuradha Mudannayake, B.Tech. Eng.(Hons) (OUSL), M.Sc. Eng.(Moratuwa), M.BA(IGNOU), MIET(UK), MIE(SL),

C. Eng., Project Engineer, Broadlands Project,

Ceylon Electricity Board.

Email:cebgen@hotmail.com 


\subsection{Broadlands Mini Hydroelectric Plant}

The main dam of BHP will have a direct impact on WWR related activities. To mitigate the impact, a certain quantity of water has to be released during day time which will then reduce the amount of annual energy that can be generated by BHP. However, the possibility of recovering some of the lost energy by releasing this water to a Mini Hydroelectric Plant (MHP) located downstream of Kelani River near the main dam of BHP needs to be explored.

\subsection{Aims and Objectives}

The aims of this research study were to

- evaluate under various operational policies the energy loss of the BHP as a result of releasing water through the Broadlands MHP to cater to WWR and

- investigate the economic impact of avoiding the cost of thermal power generation under different operational conditions

The objectives of the research were to

o determine the water flow-rate by establishing a hydrological model suitable to the area concerned

o simulate the operational pattern of the Broadlands Main Pond and the Power Plant

o compute the capacities and energy generation suitable to the proposed Broadlands MHP

o investigate the economic impact of Broadlands MHP under various operational policies

\section{Methodology}

The strategy adopted for this research study can be stated briefly as follows:

1. Making several visits to the K-M complex and BHP site to identify the principal features of the Project and the conflicts that can arise with regard to WWR

2. Collecting rainfall/spilling data and Polpitiya PP energy generation data of the past 20 years

3. Developing a hydrological model suitable to the catchment area concerned for determining the surface runoff and watershed

4. Simulating the Broadlands Main Pond in relation to the expected operation of the Broadlands PP
5. Determining the expected rated capacities, and amount of energy generated under various operational policies of the proposed Broadlands MHP

6. Identifying the economic impact of the Project on WWR

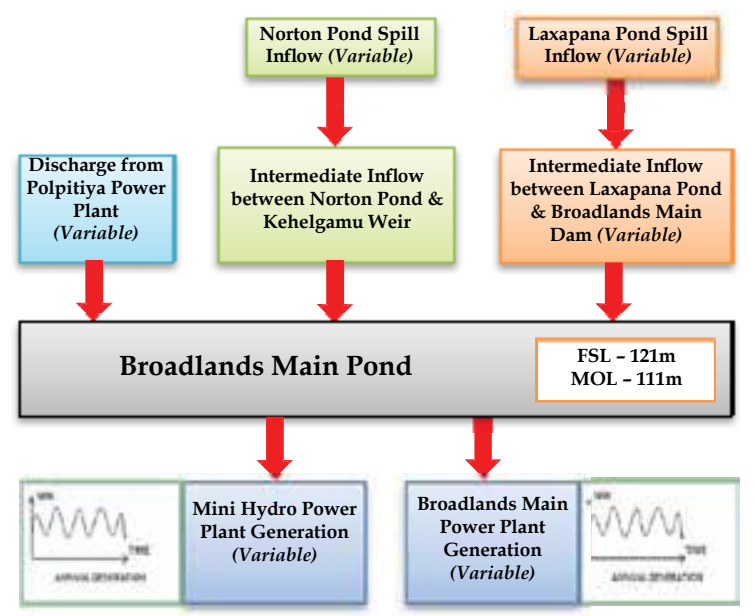

Figure 1 - Free Open System

The algorithmic work flow chart is shown in Figure 2.

The free open system led to the development of the proposed methodology shown in Figure 1.

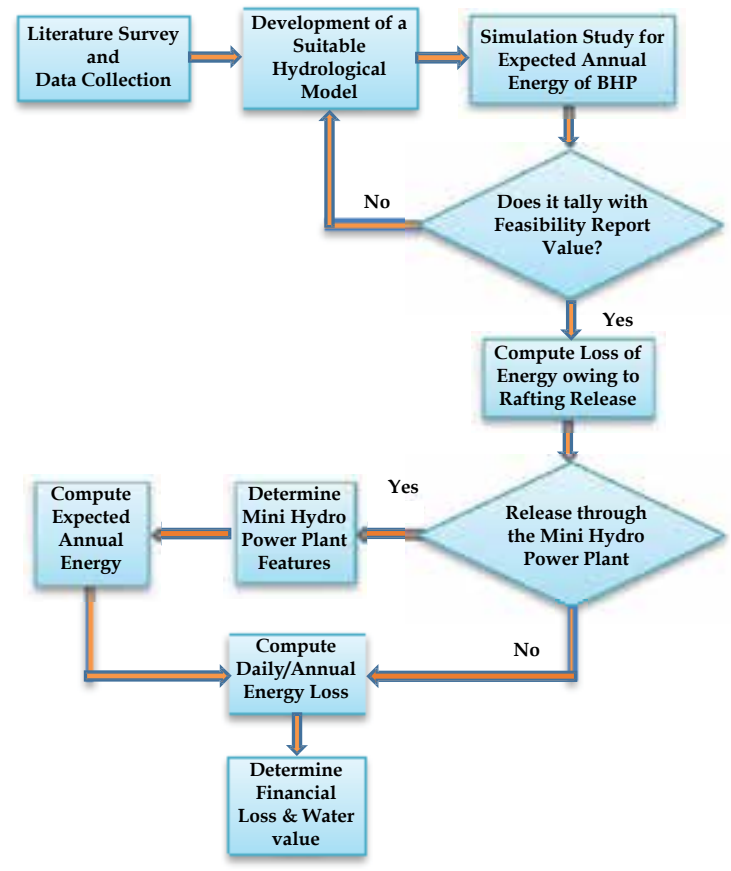

Figure 2 - Flow Chart - Methodology 


\section{Data Collection}

\subsection{BHP Water Resource and its Potential}

The catchment area of the BHP, highlighted in yellow in Figure 4 in Appendix-A, consists of the area between Norton Pond and KehelgamuOya Weir and the area between Laxapana Pond and Broadlands Main Pond. This was found to be $62.5 \mathrm{sq} . \mathrm{km}$ in area [1]. It is reasonable to assume that the rate of outflow of water at Polpitiya PP is equal to the rate of inflow of water from the upstream zones of Norton and Laxapana Catchment Areas.

\subsection{Polpitiya Water Outflow Rates}

A significant factor that has to be considered when comparing different types of turbines is their relative efficiencies both at their design points and at reduced flows [3]. Therefore, the turbine efficiency curve plays an important role by indicating the power output for a particular discharge flow-rate of water.

Since no turbine efficiency curve applicable for a broad spectrum of operations (specially for part and low loads) was available for the Polpitiya PP, the tailrace water level and the velocity of the discharged water had to be measured for each active power load (Table-1).

Table 1 - Measurements taken at the tailrace

\begin{tabular}{|c|c|c|}
\hline Load (MW) & Level (m) & Speed (m/s) \\
\hline 5 & 1.2 & 0.63 \\
\hline 32 & 1.8 & 1.05 \\
\hline
\end{tabular}

\subsection{Rainfall}

The flow rate can be assessed using the average rainfall data of the catchment. The following three rainfall gauging stations are situated close to the catchment area concerned:

\section{o Station No 317 E Norton \\ o Station No 317 D Laxapana \\ o Station No 317 G Polpitiya}

Daily rainfall data of the three hydrological stations and other required details over a period of about 20 years were obtained from the Meteorology Department.

\subsection{Spill Data and Rainfall Data}

Since the K-M complex is cascaded, the details of spill data at Norton and Laxapana Ponds very important for the computation of water flow-rate, had to be obtained.

Norton Pond has a natural spill way system while Laxapana Pond has three radial gate arrangements. The daily spill data of these ponds were also obtained from the Laxapana PP for the same hydrological period (19972016). Laxapana Pond spilling is shown in Figure 3.

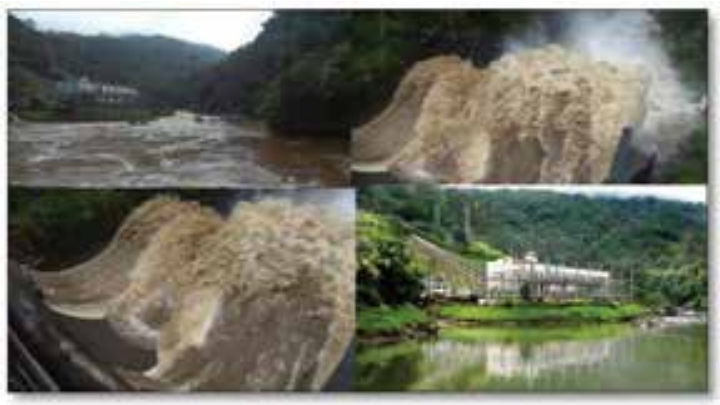

Figure 3 - Spilling of Laxapana Pond

The daily rainfall data obtained were assigned/ divided into drainage areas of the corresponding rainfall gauging stations as shown in Table 2.

Table 2 - Area relationship

\begin{tabular}{|l|c|c|c|}
\hline $\begin{array}{c}\text { Site } \\
\text { location }\end{array}$ & $\begin{array}{c}\text { Norton } \\
(\mathbf{3 1 7 E}) \\
\left.\mathbf{( k m}^{\mathbf{2}}\right)\end{array}$ & $\begin{array}{c}\text { Laxapana } \\
\mathbf{( 3 1 7 D )} \\
\mathbf{( k m}^{\mathbf{2}}\end{array}$ & $\begin{array}{c}\text { Polpitiy } \\
\mathbf{a}(\mathbf{3 1 7 G}) \\
\mathbf{( k m}^{\mathbf{2}}\end{array}$ \\
\hline Main am & 0.48 & 12.46 & 16.56 \\
\hline Kehel gamu & 14.56 & 0.00 & 18.45 \\
\hline
\end{tabular}

The following "Rational Formula" was used for the computation of the water flow-rate.

$$
\mathrm{Q}=\text { CIA [2], }
$$

$\begin{array}{rll}\text { where } & \text { Q: } & \text { Water Flow Rate Due to } \\ & \text { Runoff }\left(\mathrm{m}^{3} / \mathrm{s}\right) \\ & \text { I: } & \text { Runoff coefficient } \\ \text { (dimensionless) } & \text { Rainfall Intensity }(\mathrm{m} / \mathrm{s}) \\ \text { A: } & \text { Drainage area }\left(\mathrm{m}^{2}\right)\end{array}$

\subsection{Inflow due to Rainfall}

The average inflow rates resulting from the rainfall in the catchments between Norton Pond and Kehelgamu Weir and between Laxapana Pond and Broadlands Main Dam are graphically presented in Figure 4.

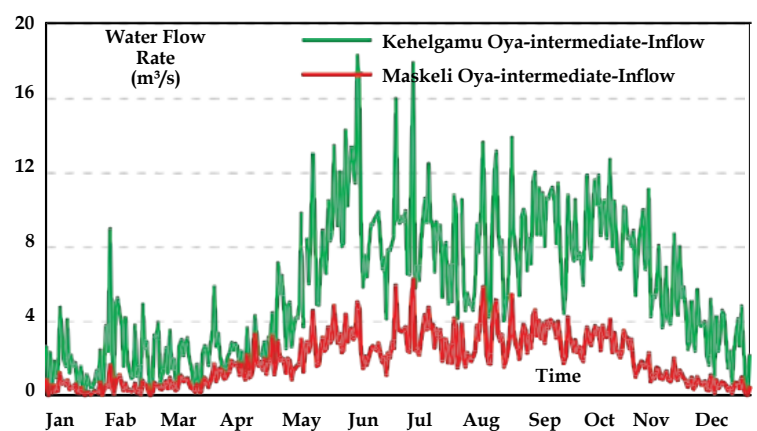

Figure 4 - Intermediate average inflow pattern between Norton Pond and Kehelgamu weir and Laxapana Pond and Broadlands Main Dam 


\subsection{Inflow Resulting from Spill}

The average inflow patterns of the past 20 year sresulting from Norton and Laxapana Pond spills are graphically presented in Figure-5.

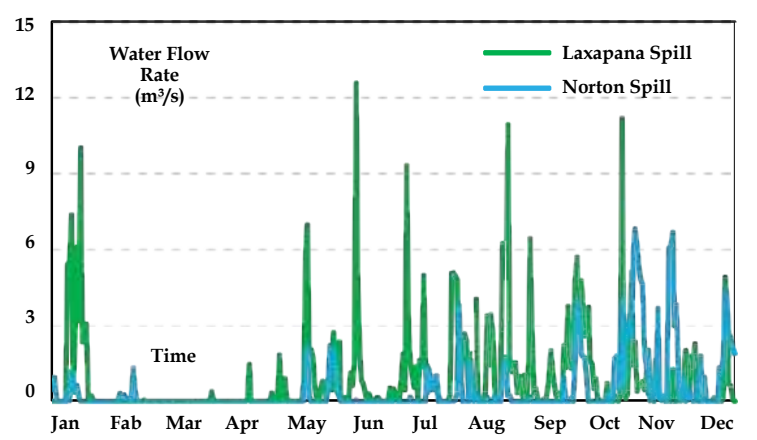

Figure 5 - Inflows resulting from Norton Pond and Laxapana Pond spills

\subsection{Discharge Water Flow-Rate of the Polpitiya Power Plant}

The two 37.5 MW hydraulic turbines at the Polpitiya Power Plant both experience vibrational and shaft run-out problems when loaded synchronously. As such, only the operational sequences, 5, 32 and $37.5 \mathrm{MW}$ are permitted for each generator. This way, both units at the Polpitiya Power Plant can beoperated wirh nine different loading configurations and Table 3 presents the corresponding discharge water flow rates .

Table 3 - Loading patterns and discharge water flow rates of the Polpitiya PP

\begin{tabular}{|c|c|c|c|}
\hline $\begin{array}{c}\text { Unit-1 } \\
\text { load } \\
\text { (MW) }\end{array}$ & $\begin{array}{c}\text { Unit-2 } \\
\text { load } \\
\text { (MW) }\end{array}$ & $\begin{array}{c}\text { Total } \\
\text { load } \\
\text { (MW) }\end{array}$ & $\begin{array}{c}\text { Discharge } \\
\text { water flow-rate } \\
\text { ( }^{3} / \mathbf{s} \text { ) }\end{array}$ \\
\hline 5 & 0 & 5 & $\mathbf{5 . 6}$ \\
\hline 5 & 5 & 10 & $\mathbf{1 1 . 2}$ \\
\hline 32 & 0 & 32 & $\mathbf{1 4 . 1}$ \\
\hline 5 & 32 & 37 & $\mathbf{1 9 . 7}$ \\
\hline 37.5 & 0 & 37.5 & $\mathbf{1 5 . 8}$ \\
\hline 37.5 & 5 & 42.5 & $\mathbf{2 1 . 4}$ \\
\hline 32 & 32 & 64 & $\mathbf{2 8 . 2}$ \\
\hline 37.5 & 32 & 69.5 & $\mathbf{2 9 . 9}$ \\
\hline 37.5 & 37.5 & 75 & $\mathbf{3 1 . 7}$ \\
\hline
\end{tabular}

The tailrace water levels along with the velocity of tail water discharged for each active power load at the Polpitiya Power Plant had to be measured and hourly data from the System Control Centre and Laxapana Power Plant of the Ceylon Electricity Board for a twenty-year study period had to be collected as described in Section 3.2.

The average out-flow rate at the Polpitiya Power Plant is shown in Figure 6.

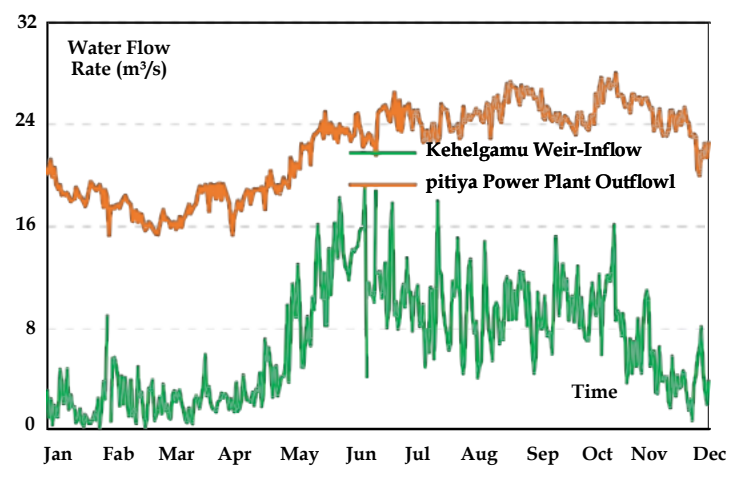

Figure 6 - Inflow-rate at Kehelgamu Weir \& outflow-rate at Polpitiya Power

Plant

\subsection{Inflow from Kehelgamu Oya Weir through the Water Diversion Tunnel}

Kehelgamu Oya Weir diverts the water accumulated between Norton Pond and Kehelgamu Oya Weir to Maskeli Oya through a concrete lined non-pressure diversion tunnel. The water inflow rate at Kehelgamu Oya Weir can be expressed as follows:

Inflow at Kehelgamu Oya Weir:

where Qweir $=$ Qink + Qsn $\left(\mathrm{m}^{3} / \mathrm{s}\right)$ Qink:Intermediate inflow between Norton Pond and Kehelgamu Oya Weir $\left(\mathrm{m}^{3} / \mathrm{s}\right)$

Qsn: Inflow due to Norton Spill $\left(\mathrm{m}^{3} / \mathrm{s}\right)$

The inflow pattern at Kehelgamu Oya Weir is presented in Figure 7.

\subsection{Inflow at the BHP Main Dam}

Inflow at the Broadlands Main Dam can be expressed as follows:

$$
\text { Qdam }=Q p+Q w e i r+Q \text { inm }+ \text { Qsl }
$$

where Qdam: Inflow at main dam $\left(\mathrm{m}^{3} / \mathrm{s}\right)$

Qp: Polpitiya PP discharge $\left(\mathrm{m}^{3} / \mathrm{s}\right)$

Qweir: Inflow from weir $\left(\mathrm{m}^{3} / \mathrm{s}\right)$

Qinm: Intermediate inflow between Laxapana Pond and Broadlands Main Dam due to rain fall $\left(\mathrm{m}^{3} / \mathrm{s}\right)$

Qsl: Inflow due to Laxapana Pond spill $\left(\mathrm{m}^{3} / \mathrm{s}\right)$

The annual average inflow pattern at the Broadlands Main Dam is shown in Figure 7. 


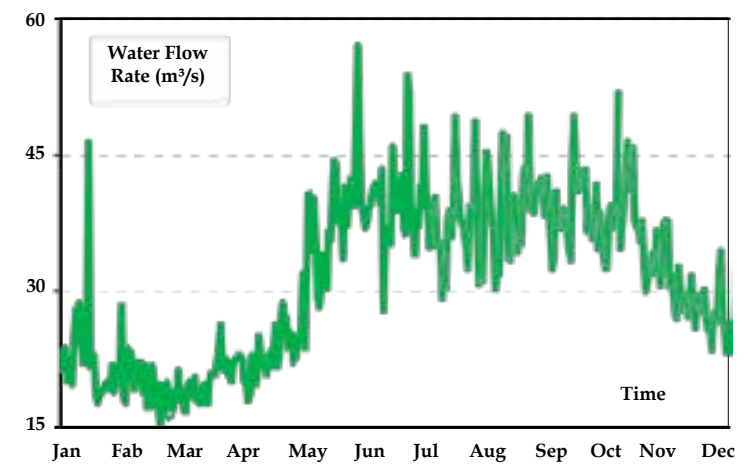

Figure 7 - Annual average inflow at Broadlands Main Dam

Figure 8 shows the Flow Duration Curve (FDC) based on the daily inflow of the whole study period.

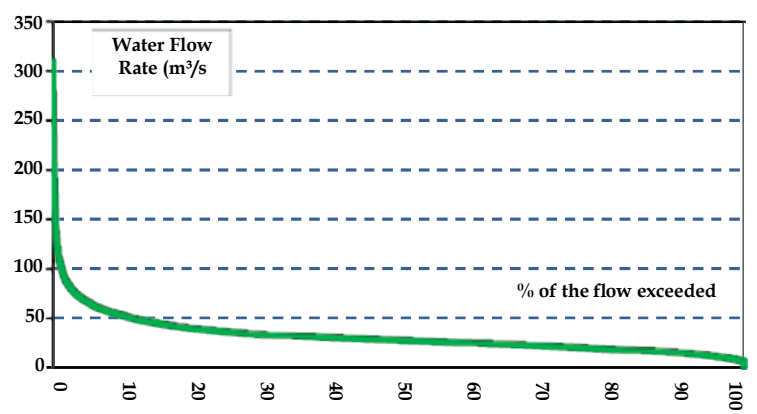

Figure 8 - FDC of the Main Dam based on the daily inflow

3.10 Representation of Main Dam Levels The hydrograph in Figure 9 shows the level variation of BHP Main Dam throughout the year and for any particular value of the level, there are months during which the level would exceed that value.

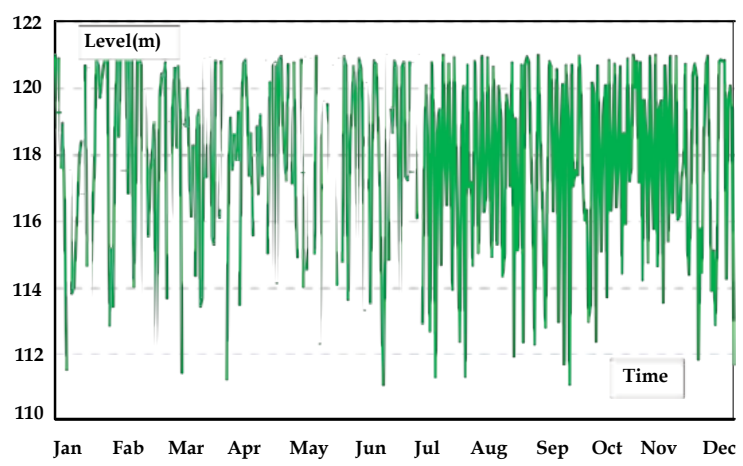

\section{Figure 9 - Broadlands Main Dam annual} level variation

Figure 10 shows the same information represented in the form of an "Exceedance Curve".

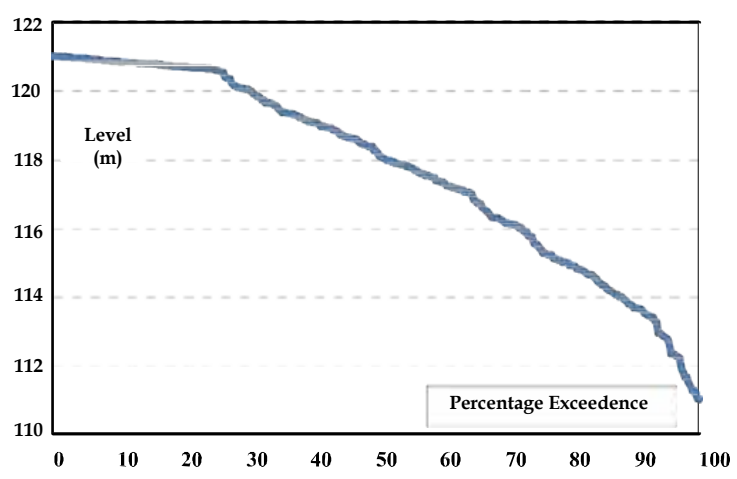

Figure 10 - Level exceedance curve at the Main Dam

\section{Generation Pattern of BHP}

BHP is identified as a committed run-of-theriver type power plant with a maximum discharge of $70 \mathrm{~m}^{3} / \mathrm{s}$ and an installed capacity of 2x17.5 MW [4].

\subsection{Broadlands Pond}

The significant features of the Broadlands Main Pond are shown in Table 4.

Table 4 - Features of the Broadlands Pondage

\begin{tabular}{|l|c|}
\hline Total storage capacity & $216,000 \mathrm{~m}^{3}$ \\
\hline Effective storage capacity & $198,000 \mathrm{~m}^{3}$ \\
\hline Impounded area & $37,700 \mathrm{~m}^{3}$ at EL. $122 \mathrm{~m}$ \\
\hline Flood water level & $122 \mathrm{~m}$ \\
\hline Max. operation water level & $121 \mathrm{~m}$ \\
\hline Min. operation water level & $111 \mathrm{~m}$ \\
\hline
\end{tabular}

Source: "Study of Hydropower Optimization in Sri Lanka" [4]

\subsection{Reservoir Elevation-Storage Curve}

One of the most important physical characteristics of a reservoir is its elevation-storage curve. Elevation " $y$ " $(\mathrm{m})$ and volume " $\mathrm{x}$ " $\left(\mathrm{m}^{3}\right)$ of a reservoir have a physical relationship which is dependent on the topography of the surrounding area. A mathematical function for the elevation-storage curve for the reservoir can be established. In most cases, linear simplification is applied, and $\mathrm{y}$ is approximated using the linear relationship, $y=\alpha_{0} x+\alpha_{i}$, where $y$ is the elevation of the water surface above a given reference level. It is piece-wise linear and can be computed using elevation-storage data [4].

Reservoir elevation-storage relationship between max. operation water level (121.0 $\mathrm{m})$ and min. operation water level $(111.0 \mathrm{~m})$ was obtained using the following equations developed using the curves shown in Figure 5 in Appendix-A. 


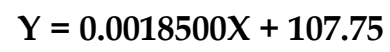

$\left(111.0 \mathrm{~m} \leq \mathrm{Y} \leq 112.5 \mathrm{~m} \& 18918 \mathrm{~m}^{3} \leq \mathrm{X} \leq 25675 \mathrm{~m}^{3}\right)$

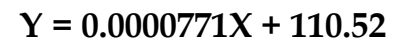

$\left(112.5 \mathrm{~m} \leq \mathrm{Y} \leq 114.38 \mathrm{~m} \& 25675 \mathrm{~m}^{3} \leq X \leq 50000 \mathrm{~m}^{3}\right)$

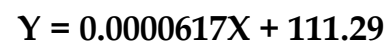

$\left(114.38 \mathrm{~m} \leq \mathrm{Y} \leq 116.88 \mathrm{~m} \& 50000 \mathrm{~m}^{3} \leq X \leq 90541 \mathrm{~m}^{3}\right)$

$$
\mathrm{Y}=\mathbf{0 . 0 0 0 0 4 3 4 X + 1 1 2 . 9 5}
$$

$\left(116.88 \mathrm{~m} \leq \mathrm{Y} \leq 120.63 \mathrm{~m} \& 90541 \mathrm{~m}^{3} \leq X \leq 177027 \mathrm{~m}^{3}\right)$

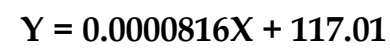

$\left(120.63 \mathrm{~m} \leq \mathrm{Y} \leq 21.0 \mathrm{~m} \& 177027 \mathrm{~m}^{3} \leq \mathrm{X} \leq 222973 \mathrm{~m}^{3}\right)$

\subsection{Energy Generation at the Broadlands PP}

The amount of annual energy expected to be generated by the Broadlands PP was computed considering the annual average inflow pattern at the Broadlands Main Dam. The simulation study indicated that the total annual expected energy of the Broadlands PP is 137.98 GWh which validates the JAICA [4] results. Energy duration curve of the Broadlands PP is shown in Figure 11.

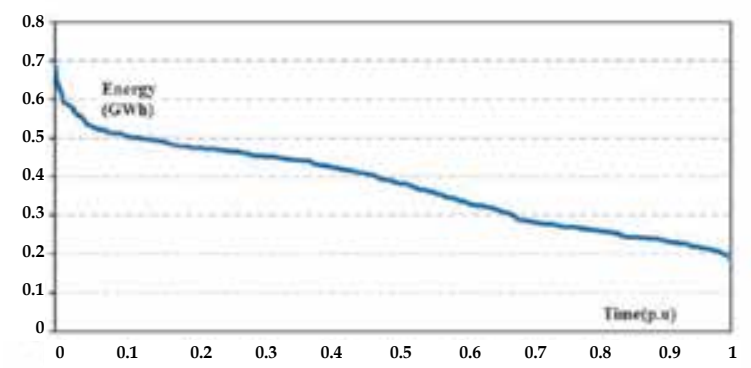

Figure 11 - Expected daily energy generation of Broadlands PP based on the annual average inflow

The expected annual firm energy yield at $98 \%$ probability is $76.4 \mathrm{GWh}$ and the expected annual secondary energy is $61.6 \mathrm{GWh}$.

\section{Energy Loss due to Water Released for Rafting Activities}

The amount of water to be released for WWR was used as the input variable. The outputs were the annual amount of energy expected to be generated by the Broadlands PP and the amount of energy lost by the release of water for WWR. Two proposals were prepared in this regard. Water discharge was taken as a variable and the period during which water was released was taken as $8 \mathrm{hrs}$. Proposal-1 presumed that water was released for WWR throughout the year although in reality, WWR is not possible throughout the year, i.e., during very dry periods and during floods. Proposal-2 was based on this fact.

\subsection{Proposal-1}

Simulation studies were carried out on the basis that the amount of water released for WWR throughout the year including the dry period varied from $6 \mathrm{~m}^{3} / \mathrm{s}$ to $20 \mathrm{~m}^{3} / \mathrm{s}$ from 9.00 a.m. to 5.00 p.m daily. The expected amount of annual energy generated by the Broadlands PP and the amount of energy lost due to the water released for rafting are shown in Table 5.

Table 5 - Annual energy expectation/loss due to water released for rafting (Dry season was not considered)

\begin{tabular}{|c|c|c|c|}
\hline $\begin{array}{c}\text { Proposal } \\
\text { I }\end{array}$ & $\begin{array}{c}\text { Water } \\
\text { discharge } \\
\left(\mathbf{m}^{\mathbf{3}} / \mathbf{s}\right)\end{array}$ & $\begin{array}{c}\text { Expected } \\
\text { generation } \\
\mathbf{( G W h )}\end{array}$ & $\begin{array}{c}\text { Loss of } \\
\text { energy } \\
\mathbf{( G W h} \text { ) }\end{array}$ \\
\hline 1 & 6 & 129.22 & 8.76 \\
\hline 2 & 7 & 127.76 & 10.22 \\
\hline 3 & 8 & 126.30 & 11.68 \\
\hline 4 & 9 & 124.84 & 13.14 \\
\hline 5 & 10 & 123.38 & 14.60 \\
\hline 6 & 11 & 121.92 & 16.06 \\
\hline 7 & 12 & 120.46 & 17.52 \\
\hline 8 & 13 & 119.00 & 18.98 \\
\hline 9 & 14 & 117.54 & 20.44 \\
\hline 10 & 15 & 116.08 & 21.90 \\
\hline 11 & 16 & 114.62 & 23.36 \\
\hline 12 & 17 & 113.16 & 24.82 \\
\hline 13 & 18 & 111.70 & 26.28 \\
\hline 14 & 19 & 110.24 & 27.74 \\
\hline 15 & 20 & 108.78 & 29.20 \\
\hline
\end{tabular}

\subsection{Proposal-2}

To identify the dry season of the year, the percentage contribution made by Maskeli Oya, Kehelgamu Oya and Polptiya PP discharge to the inflow of Broadlands Pond were considered. The detailed percentage contribution made to the energy generated by the Laxapana Complex during the 20 year period considered is shown in Figure 12.

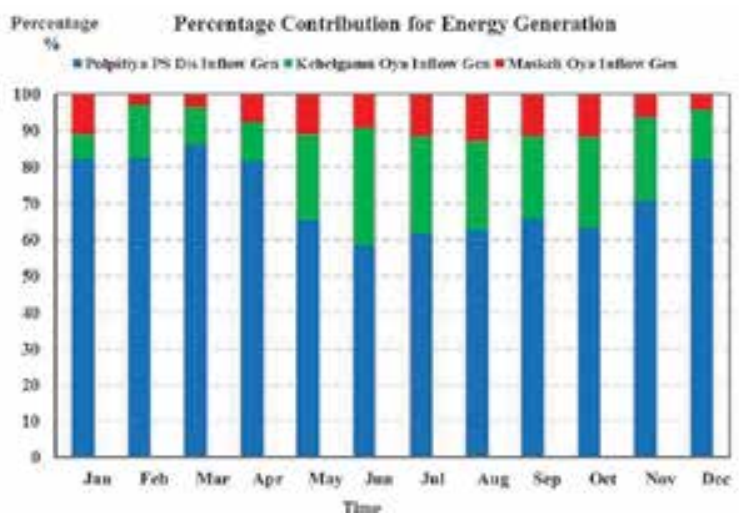

Figure 12 - Maskeli Oya, Kehelgamu Oya inflows and Polpitiya discharge 
As can be seen from Figure 12, the major contribution to the Broadlands PP has been made by the Polpitiya discharge. Therefore, the pattern of the water discharged downstream had to be further studied using the hourly active power readings of the Polpitiya PP taken during the 20-year period. The active power duration curve of the Polpitiya PP is shown in Figure 13. It is clear from Figure 13 that WWR is not possible during certain periods due to lack of water in the stream. This can be identified from the Polpitiya PP loading configuration for the corresponding minimum water discharge ( Table 6) .

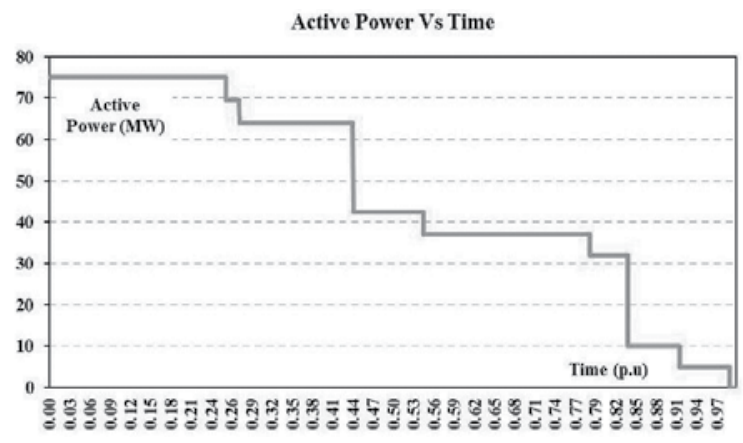

Figure 13 - Power Duration Curve of Polpitiya Power Plant

Table 6 - Loading of Polpitiya Power Plant during minimum water discharge

\begin{tabular}{|c|c|c|}
\hline $\begin{array}{c}\text { Unit-1 Load } \\
\text { (MW) }\end{array}$ & $\begin{array}{c}\text { Unit- 2 Load } \\
\text { (MW) }\end{array}$ & $\begin{array}{c}\text { Total Load } \\
\text { (MW) }\end{array}$ \\
\hline 0 & 0 & 0 \\
\hline 5 & 0 & 5 \\
\hline 0 & 5 & 5 \\
\hline 5 & 5 & 10 \\
\hline
\end{tabular}

The graphical interpretation showed that rafting was not possible during approximately 57 days of the year. Simulation was then carried out considering the dry period and the values obtained for the expected amounts of annual energy generated/loss are shown in Table 7.

Table 7- Annual energy expectation/loss due to water released for rafting considering the dry season

\begin{tabular}{|c|c|c|c|}
\hline $\begin{array}{c}\text { Proposal } \\
\text { II }\end{array}$ & $\begin{array}{c}\text { Water } \\
\text { Discharge } \\
\left(\mathbf{m}^{\mathbf{3}} \mathbf{s} \mathbf{)}\right.\end{array}$ & $\begin{array}{c}\text { Expected } \\
\text { Generation } \\
\mathbf{( G W h )}\end{array}$ & $\begin{array}{c}\text { Loss of } \\
\text { Energy } \\
\mathbf{( G W h )}\end{array}$ \\
\hline 1 & 6 & 130.59 & 7.39 \\
\hline 2 & 7 & 129.36 & 8.62 \\
\hline 3 & 8 & 128.12 & 9.86 \\
\hline 4 & 9 & 126.89 & 11.09 \\
\hline 5 & 10 & 125.66 & 12.32 \\
\hline 6 & 11 & 124.43 & 13.55 \\
\hline 7 & 12 & 123.20 & 14.78 \\
\hline 8 & 13 & 121.96 & 16.02 \\
\hline 9 & 14 & 120.73 & 17.25 \\
\hline 10 & 15 & 119.50 & 18.48 \\
\hline
\end{tabular}

\begin{tabular}{|l|l|l|l|}
\hline 11 & 16 & 118.27 & 19.71 \\
\hline 12 & 17 & 117.04 & 20.94 \\
\hline 13 & 18 & 115.80 & 22.18 \\
\hline 14 & 19 & 114.57 & 23.41 \\
\hline 15 & 20 & 113.34 & 24.64 \\
\hline
\end{tabular}

\section{Impact on Environmental Release}

According to the Environmental Impact Assessment (EIA) of BHP, a continuous discharge of $0.2 \mathrm{~m} 3 / \mathrm{s}$ has to be present to cater to water requirements downstream. At the time of preparation of the EIA, WWR was not a significant activity. However, at the time of commencing the project, WWR had developed well and the CEB decided to release water to maintain it. In this scenario, it was worth studying the impact of minimum environmental release (E-flow) to the BHP energy yield. This study concentrated on all possibilities and the results are presented in Table 8.

Table 8 - Impact of E-flow to BHP generation

\begin{tabular}{|l|c|}
\hline E-flow option & $\begin{array}{c}\text { BHP generation } \\
\text { (GWh) }\end{array}$ \\
\hline Without E-flow & 139.03 \\
\hline From the weir only & 138.69 \\
\hline From the main dam only & 137.98 \\
\hline $\begin{array}{l}\text { From both the weir } \\
\text { and main dam }\end{array}$ & 137.63 \\
\hline
\end{tabular}

\section{Economic Impact}

The economic impact of the water released for WWR was evaluated based on the following:

I. Economic loss without Broadlands MHP

II. Economic loss with Broadlands MHP

7.1 Scenario-I (without mini hydro PP) Table 9 presents the expected daily loss of power and energy from the Broadlands PP during 8 hrs with the amount of water released varying from $6 \mathrm{~m}^{3}$ to $20 \mathrm{~m}^{3}$.

Table 9 - Expected daily loss of power and energy (without mini hydro PP)

\begin{tabular}{|c|c|c|}
\hline $\begin{array}{l}\text { Quantity of } \\
\text { water } \\
\text { released } \\
\left(\mathbf{m}^{3} \mathbf{s}\right)\end{array}$ & $\begin{array}{l}\text { Energy loss } \\
\text { (GWh/Day) }\end{array}$ & $\begin{array}{l}\text { Power loss for } \\
\text { 8hrs (MW) }\end{array}$ \\
\hline 6 & 0.024 & 3.0 \\
\hline 7 & 0.028 & 3.5 \\
\hline 8 & 0.032 & 4.0 \\
\hline 9 & 0.036 & 4.5 \\
\hline
\end{tabular}




\begin{tabular}{|l|l|l|}
\hline 10 & 0.040 & 5.0 \\
\hline 11 & 0.044 & 5.5 \\
\hline 12 & 0.048 & 6.0 \\
\hline 13 & 0.052 & 6.5 \\
\hline 14 & 0.056 & 7.0 \\
\hline 15 & 0.060 & 7.5 \\
\hline 16 & 0.064 & 8.0 \\
\hline 17 & 0.068 & 8.5 \\
\hline 18 & 0.072 & 9.0 \\
\hline 19 & 0.076 & 9.5 \\
\hline 20 & 0.080 & 10.0 \\
\hline
\end{tabular}

\subsection{Scenario-II (with mini hydro PP)}

As shown in Table 10, in Scenario-II,the rated output of the Broadlands MHP would vary when the quantity of water that was discharged varied from $6 \mathrm{~m}^{3}$ to $20 \mathrm{~m}^{3}$.

Table 10 - Rated output of the turbines

\begin{tabular}{|c|c|}
\hline $\begin{array}{c}\text { Quantity of water } \\
\text { discharged }\end{array}$ & $\begin{array}{c}\text { Rated output of the } \\
\text { turbine (kW) }\end{array}$ \\
\hline 6 & 1061 \\
\hline 7 & 1238 \\
\hline 8 & 1415 \\
\hline 9 & 1592 \\
\hline 10 & 1769 \\
\hline 11 & 1946 \\
\hline 12 & 2122 \\
\hline 13 & 2300 \\
\hline 14 & 2476 \\
\hline 15 & 2653 \\
\hline 16 & 2830 \\
\hline 17 & 3007 \\
\hline 18 & 3184 \\
\hline 19 & 3360 \\
\hline 20 & 3538 \\
\hline
\end{tabular}

\subsection{Avoided Cost of Thermal Power} Generation

The water value of the Broadlands Pond would depend highly on the avoided cost of generation of the power system at the time of operation. For this purpose, the daily cost values of the generation units of all the power plants were obtained from the System Control Centre (SCC) of CEB for two consecutive years.

In this computation, all non- dispatchable power plants and the major hydro power plants were not considered and only the thermal power plants were considered. Lakvijaya coal plant was also not considered as it operated only as a base load power plant.

It was noticed that in actual practice, the remaining thermal power plants are dispatched by SCC in a variable manner based on various operational regimes. Therefore, the water values of the Broadlands Pond were computed as shown in Figure 14 under the following four scenarios.

$>$ Scenario 01 Average unit cost values of Sapugaskanda B1 and B2 heavy fuel plants, Barge, Sapugaskanda A Heavy fuel, KCCPNaptha, KCCP-Diesel, Uthuru Janani, AES, West Coast, Asia Power and ACEEmbilipitiya.

\section{Scenario 02 Unit cost values of KPS (GT7)}

\section{Scenario 03 Unit cost values of KPS (GTs)}

Scenario 04 Average unit cost values of Sapugaskanda B1 and B2 Heavy fuel plants, Barge, Sapugaskanda A Heavy fuel, KCCPNaptha, KCCP-Diesel, Uthuru Janani, AES, West Coast, Asia Power, ACE-Embilipitiya and KPS (GT7), KPS (GTs)

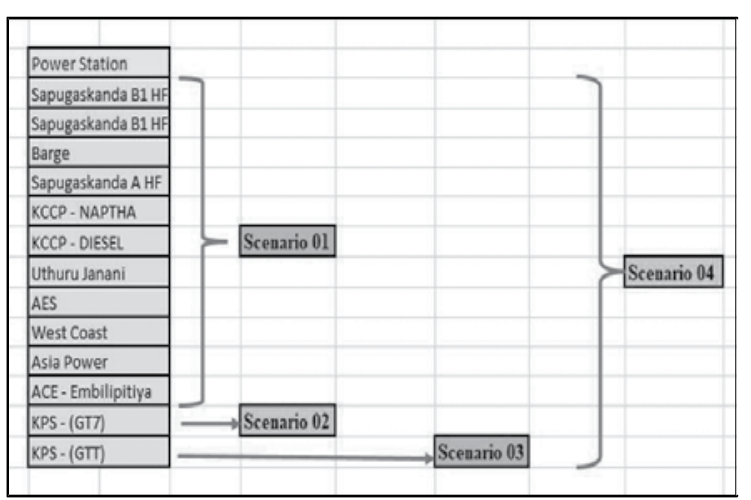

Figure 14 - Four scenarios considered for the computation of unit cost values

The above four scenarios followed by three sensitivity cases were considered for assessing the economic impact as described below:

- For prevailing unit cost of generation

- $\quad+5 \%$ to the prevailing unit cost values

- $-5 \%$ to the prevailing unit cost values

For this purpose, the amount of annual energy expected to be generated by the Broadlands MHP required was computed using Proposal1 and Proposal-2 as explained in Sections 5.1 and 5.2.

The results are presented in Table 11. 
Table 11 - Expected annual energy generation of the Broadlands MHP

\begin{tabular}{|c|c|c|}
\hline $\begin{array}{c}\text { Rafting } \\
\text { release } \\
\mathbf{8 h r s .} \\
\left(\mathbf{m}^{3} \mathbf{s}\right)\end{array}$ & $\begin{array}{c}\text { Release } \\
\text { throughout the } \\
\text { year } \\
\text { (GWh/year) }\end{array}$ & $\begin{array}{c}\text { Release } \\
\text { considering } \\
\text { the dry period } \\
\text { (GWh/year) }\end{array}$ \\
\hline 6 & 3.10 & 2.62 \\
\hline 7 & 3.62 & 3.05 \\
\hline 8 & 4.13 & 3.49 \\
\hline 9 & 4.65 & 3.92 \\
\hline 10 & 5.17 & 4.36 \\
\hline 11 & 5.68 & 4.79 \\
\hline 12 & 6.20 & 5.23 \\
\hline 13 & 6.71 & 5.67 \\
\hline 14 & 7.23 & 6.10 \\
\hline 15 & 7.75 & 6.54 \\
\hline 16 & 8.26 & 6.97 \\
\hline 17 & 8.78 & 7.41 \\
\hline 18 & 9.30 & 7.85 \\
\hline 19 & 9.81 & 8.28 \\
\hline 20 & 10.33 & 8.72 \\
\hline
\end{tabular}

Subsequently, the economic impact of the Broadlands MHP for the four scenarios explained in Section 7.3 were computed.

\section{Conclusion}

Downstream flow pattern of the Polpitiya PP was established using the inflow data of the concerned catchment areas during the past twenty years and the regulated outflow of the Polpitiya PP. It is revealed that the downstream water flow for WWR is not viable for about 57 days every year due to very low water levels caused by extremely dry weather .

\subsection{Environmental Release}

The maximum impact of the E-flow on BHP generation is found to be about $1 \%$ which is negligible compared to the energy loss expected due to WWR.

\subsection{Daily Energy Losses}

The daily energy losses computed for with and without Broadlands MHP are shown in Table 12. It is noted that the percentage of the daily energy loss is not dependant on the Broadlands Pond water value and WWR discharge water quantity values.

Table 12 - Daily Energy Loss

\begin{tabular}{|c|c|c|c|}
\hline & $\begin{array}{c}\text { Without } \\
\text { mini } \\
\text { hydro }\end{array}$ & $\begin{array}{c}\text { With } \\
\text { mini } \\
\text { hydro }\end{array}$ & $\begin{array}{c}\text { Mini } \\
\text { hydro con- } \\
\text { tribution }\end{array}$ \\
\hline $\begin{array}{c}\text { \% Daily } \\
\text { energy } \\
\text { loss }\end{array}$ & 100.00 & 64.62 & 35.38 \\
\hline
\end{tabular}

\subsection{Annual Energy Losses}

The annual energy losses computed are tabulated in Table 13. Assessment was done for the following four cases.

- Case-1- Release made throughout the year without Broadlands MHP

- Case-2- Release excluding the extremely dry period and without Broadlands BHP

- Case-3- Release made throughout the year with Broadlands MHP

- Case-4- Release excluding the extremely dry period and with Broadlands MHP

Table 13 - Results of the comparison study

\begin{tabular}{|c|c|c|c|c|}
\hline $\begin{array}{c}\text { Annual } \\
\text { \% energy } \\
\text { loss }\end{array}$ & Case-1 & Case-2 & Case-3 & Case-4 \\
\cline { 2 - 5 } & 100.00 & 84.38 & 64.62 & 54.53 \\
\hline
\end{tabular}

8.4 Financial Loss due to water released

The daily financial loss due to the water for WWR are tabulated in Tables 14 \& 15. Values were computed for the four generation scenarios discussed in Section 7.3.

Table 14 - Daily average financial loss for four Scenarios-without Broadlands MHP

\begin{tabular}{|c|c|c|c|c|}
\hline & \multicolumn{4}{|c|}{ Daily average charge -MLKR } \\
\hline $\mathbf{m}^{\mathbf{3}} \mathbf{s}$ & Scenario-1 & Scenario-2 & Scenario-3 & Scenario-4 \\
\hline 6 & 0.47 & 0.78 & 1.23 & 0.56 \\
\hline 7 & 0.55 & 0.91 & 1.43 & 0.65 \\
\hline 8 & 0.62 & 1.03 & 1.64 & 0.74 \\
\hline 9 & 0.70 & 1.16 & 1.84 & 0.83 \\
\hline 10 & 0.78 & 1.29 & 2.05 & 0.93 \\
\hline 11 & 0.86 & 1.42 & 2.25 & 1.02 \\
\hline 12 & 0.94 & 1.55 & 2.46 & 1.11 \\
\hline 13 & 1.01 & 1.68 & 2.66 & 1.20 \\
\hline 14 & 1.09 & 1.81 & 2.87 & 1.30 \\
\hline 15 & 1.17 & 1.94 & 3.07 & 1.39 \\
\hline 16 & 1.25 & 2.07 & 3.27 & 1.48 \\
\hline 17 & 1.33 & 2.20 & 3.48 & 1.57 \\
\hline 18 & 1.40 & 2.33 & 3.68 & 1.67 \\
\hline 19 & 1.48 & 2.46 & 3.89 & 1.76 \\
\hline 20 & 1.56 & 2.59 & 4.09 & 1.85 \\
\hline
\end{tabular}

Table 15 - Daily average financial loss for four scenarios-with Broadlands MHP

\begin{tabular}{|c|c|c|c|c|}
\hline & \multicolumn{4}{|c|}{ Daily average charge -MLKR } \\
\hline $\mathbf{m}^{3} \mathbf{s}$ & $\begin{array}{c}\text { Scenario } \\
\mathbf{1}\end{array}$ & $\begin{array}{c}\text { Scenario } \\
\mathbf{2}\end{array}$ & $\begin{array}{c}\text { Scenario } \\
\mathbf{3}\end{array}$ & $\begin{array}{c}\text { Scenario } \\
\mathbf{4}\end{array}$ \\
\hline 6 & 0.30 & 0.50 & 0.79 & 0.36 \\
\hline 7 & 0.35 & 0.59 & 0.93 & 0.42 \\
\hline 8 & 0.40 & 0.67 & 1.06 & 0.48 \\
\hline 9 & 0.45 & 0.75 & 1.19 & 0.54 \\
\hline 10 & 0.50 & 0.84 & 1.32 & 0.60 \\
\hline 11 & 0.55 & 0.92 & 1.45 & 0.66 \\
\hline 12 & 0.60 & 1.00 & 1.59 & 0.72 \\
\hline 13 & 0.66 & 1.09 & 1.72 & 0.78 \\
\hline
\end{tabular}




\begin{tabular}{|l|l|l|l|l|}
\hline 14 & 0.71 & 1.17 & 1.85 & 0.84 \\
\hline 15 & 0.76 & 1.25 & 1.98 & 0.90 \\
\hline 16 & 0.81 & 1.34 & 2.12 & 0.96 \\
\hline 17 & 0.86 & 1.42 & 2.25 & 1.02 \\
\hline 18 & 0.91 & 1.50 & 2.38 & 1.08 \\
\hline 19 & 0.96 & 1.59 & 2.51 & 1.14 \\
\hline 20 & 1.01 & 1.67 & 2.65 & 1.20 \\
\hline
\end{tabular}

8.5 Water Value of the Broadlands Pond The average water value of the Broadlands Pond for both cases, i.e., with and without Broadlands MHP are tabulated in Table 16 and Table 17 respectively. The sensitivity of the water value to the avoided unit cost of thermal power generation is also presented.

Table 16 - Water value (without Broadlands MHP)

\begin{tabular}{|c|c|c|c|c|}
\hline \multirow{2}{*}{$\begin{array}{c}\text { Avoided } \\
\text { Unit Cost }\end{array}$} & \multicolumn{4}{|c|}{ Average Water Value (Rs. $\left./ \mathbf{m}^{3}\right)$} \\
\cline { 2 - 5 } & $\begin{array}{c}\text { Scenario } \\
\text { Prevailing }\end{array}$ & $\begin{array}{c}\text { Scenario } \\
2\end{array}$ & $\begin{array}{c}\text { Scenario } \\
3\end{array}$ & $\begin{array}{c}\text { Scenario } \\
4\end{array}$ \\
\hline $\begin{array}{c}+5 \% \\
\text { increase }\end{array}$ & 2.84 & 4.49 & 7.11 & 3.22 \\
\hline $\begin{array}{c}-5 \% \\
\text { decrease }\end{array}$ & 2.57 & 4.27 & 6.46 & 3.38 \\
\hline
\end{tabular}

Table 17 - Water value (with Broadlands MHP)

\begin{tabular}{|c|c|c|c|c|}
\hline \multirow{2}{*}{$\begin{array}{c}\text { Avoided } \\
\text { unit cost }\end{array}$} & \multicolumn{4}{|c|}{ Average water value (Rs. $\left./ \mathrm{m}^{3}\right)$} \\
\cline { 2 - 5 } & $\begin{array}{c}\text { Scenario } \\
1\end{array}$ & $\begin{array}{c}\text { Scenario } \\
2\end{array}$ & $\begin{array}{c}\text { Scenario } \\
3\end{array}$ & $\begin{array}{c}\text { Scenario } \\
4\end{array}$ \\
\hline Prevailing & 1.75 & 2.90 & 4.59 & 2.08 \\
\hline $\begin{array}{c}+5 \% \\
\text { increase }\end{array}$ & 1.84 & 3.05 & 4.82 & 2.18 \\
\hline $\begin{array}{c}-5 \% \\
\text { decrease }\end{array}$ & 1.66 & 2.76 & 4.36 & 1.97 \\
\hline
\end{tabular}

\section{Recommendations}

* Study and determine a better platform for optimising BHP energy while releasing water for WWR thereby enabling policy/ decision makers to determine the impact of the duration and amount of water to be released for WWR.

* Identify the extremely dry period of Kelani River to minimize the energy generation loss of BHP, since in reality WWR is not possible during the dry season due to lack of water.

* In this study, $19 \mathrm{~m}$ is used as the rated effective head for Broadlands MHP. Investigate whether the rated effective head can be further increased since it is a very important factor when recovering at least to some extent the energy lost.

\section{Acknowledgement}

The authors would like to express their appreciation to Eng. (Dr.) L. B. K. Laksiri, Project Director of BHP (CEB) for granting permission for this study, and Eng. (Dr.) Narendra de Silva of LECO for the assistance provided throughout the study.

\section{References}

1. Allen R. Inversin, Mycro-Hydropower Sourcebook, $3^{\text {rd }}$ ed., NRECA International Foundation, USA,1995, pp. 09-45.

2. Adam Harvey, Mycro-Hydro Design Manual, NRECA Intermediate Technology Publications, UK, 1993, pp. 27-69.

3. Prof. Q. H Nagpurwala, Hydraulic Turbines, M. S Ramaiah School of Advanced Studies.

4. "Study of Hydropower Optimization in SriLanka", Electric Power Development Co. LTD, Nippon Koei Co. LTD, Tokyo Japan, Final Report Vol. I, Main Report, February 2004.

5. “LONG TERM GENERATION EXPANSION PLAN 2015-2034", Transmission and Generation. Planning Branch, Transmission Division, Ceylon Electricity Board, Sri Lanka, July 2015 
Appendix-A

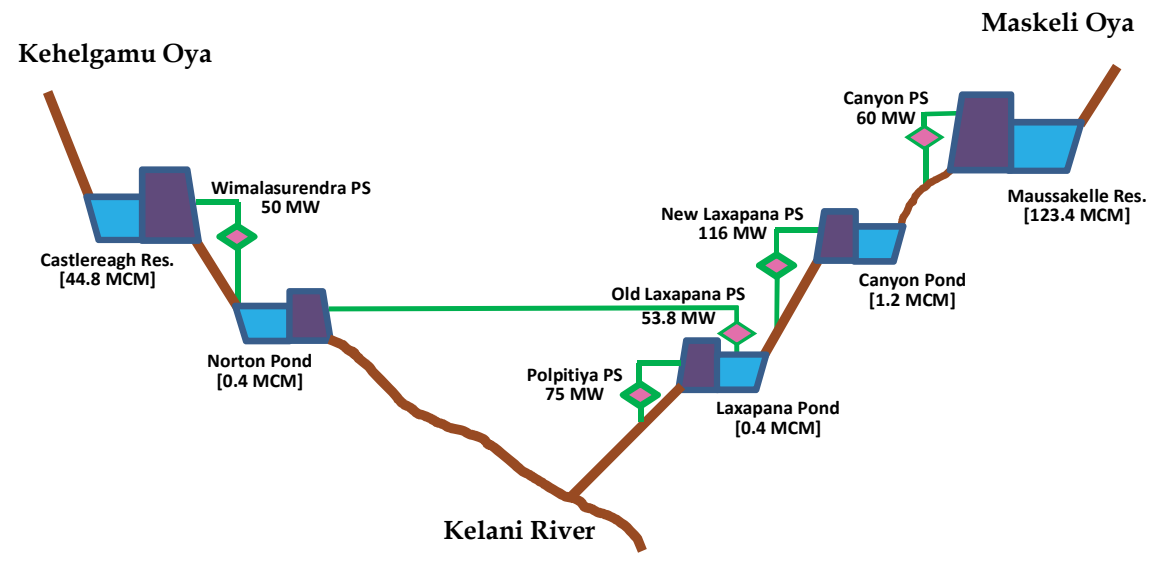

Figure 1-Existing Laxapana complex arrangement

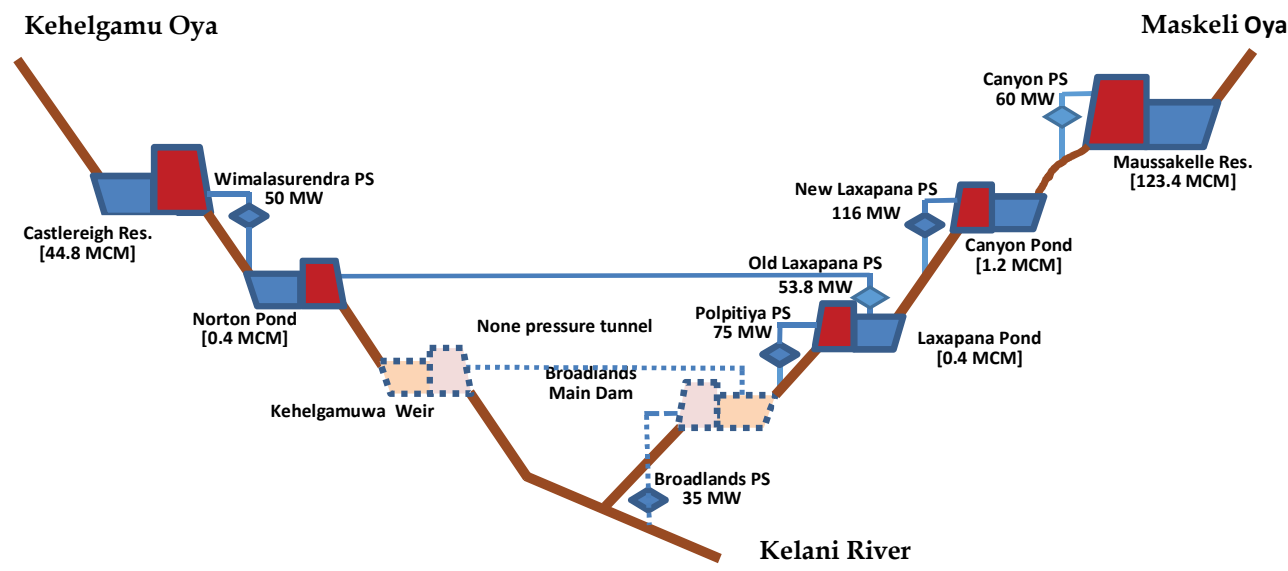

Figure 2 - Future Laxapana complex arrangement

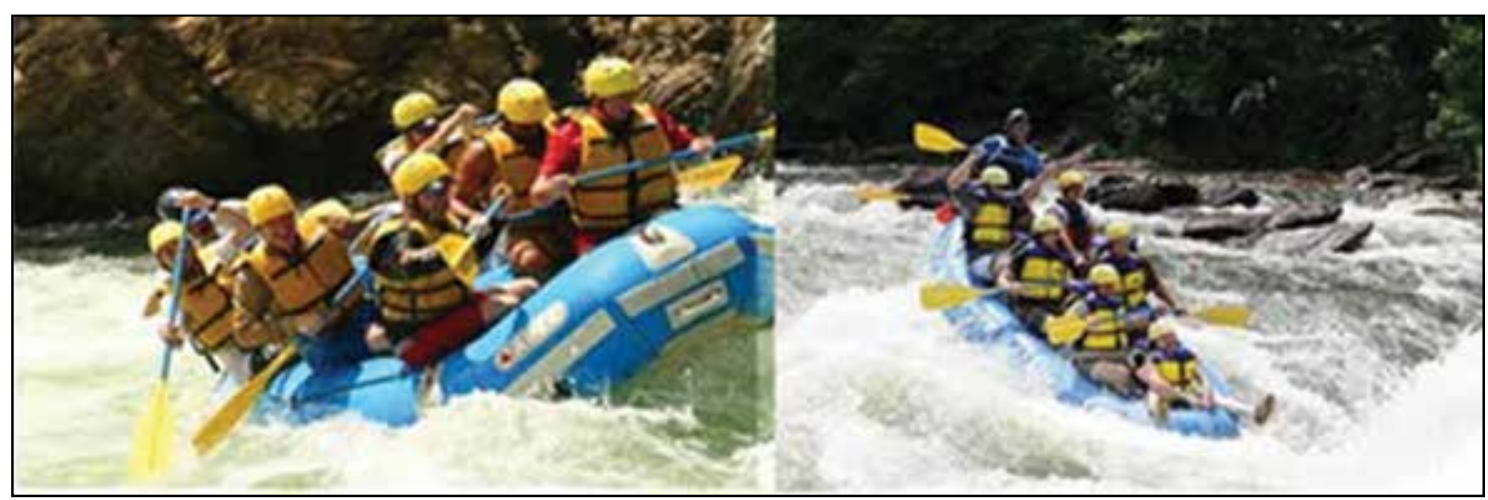

Figure 3 - White-Water rafting activity 


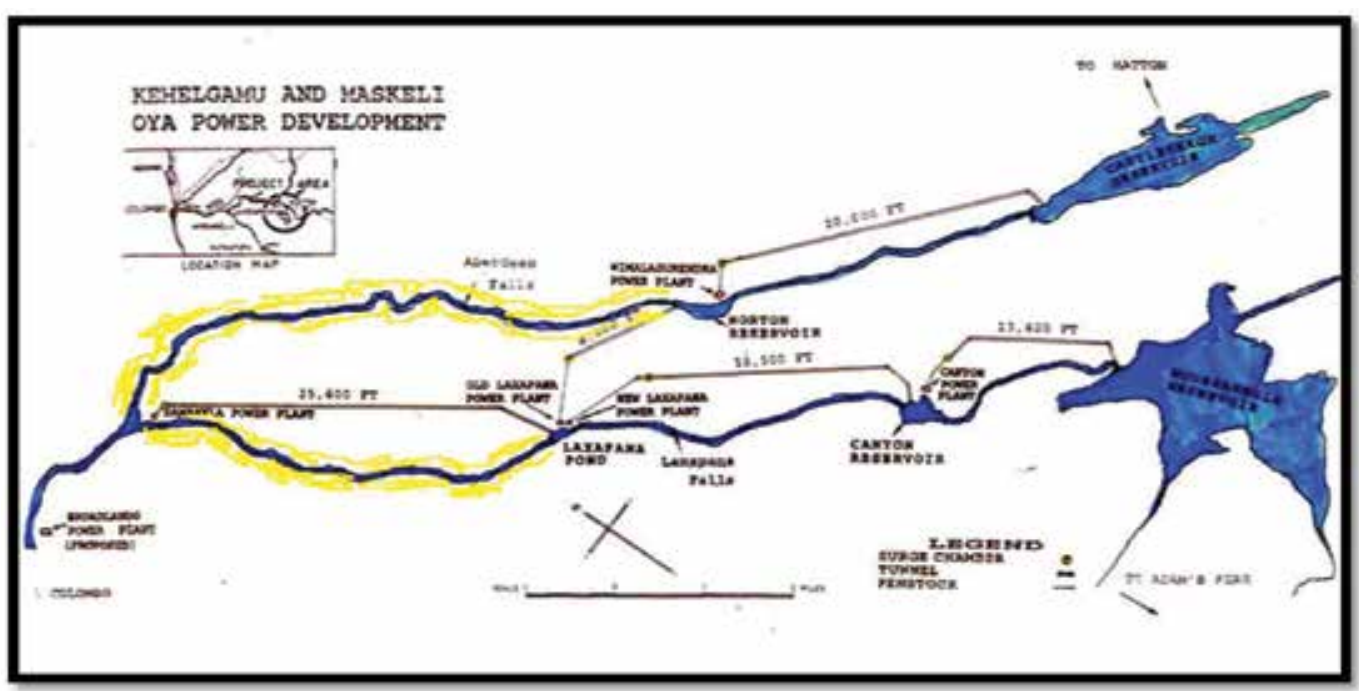

Figure 4 - Catchment area of the Broadlands hydro power project

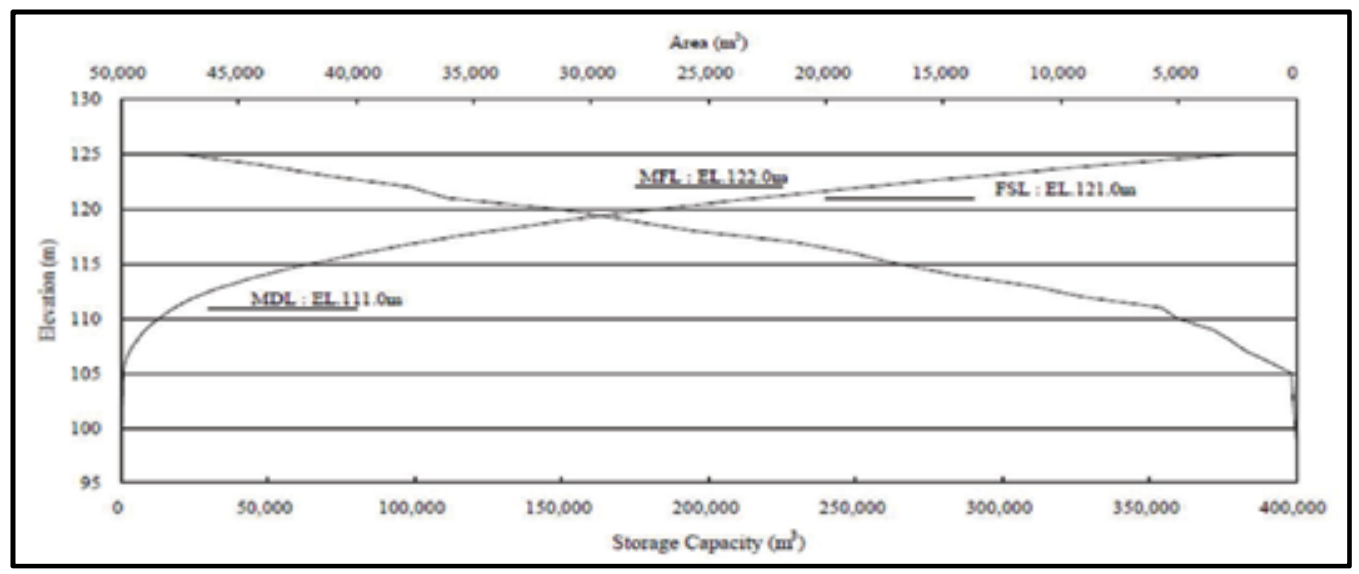

Source: "Study of Hydropower Optimization in Sri Lanka, Final Report (by Tokyo, Japan-2004)

Figure 5 - Reservoir elevation-storage capacity curve 